\title{
Family Organization and the Wage Labor Transition in a Tamang Community of Nepal
}

\author{
Thomas E. Fricke, ${ }^{1}$ Arland Thornton, ${ }^{2}$ and Dilli R. Dahal ${ }^{3}$
}

This paper explores familial contexts of transition to a wage labor economy using ethnographic and survey data from Tamang communities at the northern edge of Nepal's Kathmandu Valley. Historically agro-pastoralist, the Tamang of this area have experienced social watersheds drawing them into ever closer relationships with Kathmandu. The earliest was their nineteenth century induction into corvée labor for national elites; more recent has been the accelerating monetization of the twentieth century. This analysis demonstrates trends and frames hypotheses about the social structuring of this latest process, testing them at the individual level with combined ethnographic and survey data from 1028 respondents. Multivariate analyses explore the effects of birth cohort, education, domestic group status, and settlement location on participation in non-family organized wage work. Substantive findings are related to the broader historical literature on household and family with special attention to varieties of subsistence to monetized transition.

KEY WORDS: household; family; gender; life-course transitions; monetization; Nepal; Tamang.

\section{INTRODUCTION}

The familial context of demographic and social transition is now well established thanks to recent efforts by social scientists and historians (Caldwell, 1982; Macfarlane, 1986; Thornton and Fricke, 1987; Caldwell

${ }^{1}$ Institute for Social Research, Department of Anthropology and Population Studies Center, the University of Michigan, Ann Arbor, Michigan 48106.

${ }^{2}$ Institute for Social Research, Department of Sociology and Population Studies Center, The University of Michigan, Ann Arbor, Michigan 48106.

${ }^{3}$ Center for Nepal and Asian Studies, Department of Sociology and Anthropology, Tribhuvan University, Kathmandu, Nepal. 
et al., 1988). Nevertheless, substantial gaps impede our understanding of transition processes from family organized to wage labor market production. Although theoretical and empirical analyses suggest that increasingly nonfamily supervised participation in work and schooling are important to this transition, the actual processes by which these novel activities are introduced are seldom observed. Historical work on European and North American transformations, for example, illustrates many dimensions of change from agriculture to industry (Hareven, 1982; Kertzer and Hogan, 1989; Medick, 1976; Tilly and Scott, 1987), but is often constrained by data limitations such as restriction to a few tiers of society (Kertzer, 1984). National and regional surveys, on the other hand, often cannot relate general trends to highly localized historical events and social contexts (Caldwell, 1985). Moreover, since many of the areas for which reliable survey data exist have long before undergone a wage transition, the process of change itself is unobservable.

Nepali transitions from largely subsistence to increasingly monetized production represent an unusual opportunity for observing these watershed social processes in vivo. Although initiated at different times throughout the country since at least the early nineteenth century (Regmi, 1971, 1978), nonfamilial modes of organizing production have only recently become prevalent in many communities. This explains, in part, the coexisting studies ranging from those that focus on more or less static and local adaptations (Metz, 1989), to those that analyze changes in terms of the intensification of local production (Messerschmidt, 1976; Fricke, 1986), to those that consider the impact of outside wage-labor opportunities on local communities (Macfarlane, 1976; Bishop, 1989; Hitchcock, 1961) or the internal monetization of community production (Dahal, 1983; Toffin, 1986). While these studies indicate the importance of various dimensions of change, none of them systematically explores the intra-familial contexts within which individual lives are increasingly marked by novel experiences of schooling and wage labor. Moreover, few explore the intersection of familial relationships, defined by gender and household status, with individual activities that comprise changing household strategies. ${ }^{4}$

This analysis redresses some of these limitations by examining this social transition within a cluster of villages in Nepal's Kathmandu Valley. Combined ethnographic and survey data collection in this setting allow us to relate increasing wage labor and schooling to specific events in national and local historical time. We also contextualize the life course transition

${ }^{4}$ The expanding literature on household and family organization increasingly emphasizes the multiple activities and differential interests of members within domestic groupings, rather than earlier static models of household organization (Netting et al., 1984; Yanagisako, 1979; Wilk and Netting, 1984; Wilk, 1990). 
of entry into wage labor as it is structured by a specific family mode of organization (Thornton and Fricke, 1987). We are thus able to relate life course events to family strategies for an entire community within a rapidly changing national setting.

In what follows, we combine an integrated micro-demographic methodology, requiring that hypotheses emerge from intensive local knowledge, with the perspective of revisionist family historians who have argued that family organization fundamentally shaped the transition to industry in Europe at least as much as that transition transformed the family (Macfarlane, 1986; Kertzer and Hogan, 1989). This perspective requires that one begin with a setting's historical family organization rather than with the fact of monetization or social change. Our examination of this Nepali setting will demonstrate that the system of gender and intergenerational relations has fundamentally shaped the ongoing transition to a wage labor economy even as that transformation has implications for family relations themselves. We therefore develop expectations about social change from the point of view of community history and social organization. Next we explore the historical patterning of life course transitions within our study area. Finally, we examine the relationships between mode of organization and individual participation in wage labor.

\section{SANGILA: DOMESTIC ORGANIZATION AND HISTORICAL TIME}

Changes throughout Nepal take place in a multi-ethnic society of great complexity, composed of the descendants of Hindu and Buddhist migrants from all sides of the Himalaya. Nevertheless, these many ethnic traditions emphasize the family and kin structuring of a range of activities production, distribution, consumption, education, and social welfare (Acharya and Bennett, 1981; Bista, 1967; Nag et al., 1978; Hitchcock, 1980; Levine, 1988; Fricke, 1986; Zurick, 1989).

Sangila, a settlement cluster of 307 Tamang ${ }^{5}$ households about 3-5 miles north of the Kathmandu Urban area (see Fig. 1), has undergone dramatic social transformation within the lifetimes of its current residents. Its first settlers were Tamang who moved from the north in search of new land between 200-300 years ago. These ancestors established

${ }^{5}$ The Tamang are a Tibeto-Burmese language speaking group. Nepal's single largest ethnic identity, they inhabit the area around the Kathmandu Valley (see Höfer, 1969; Fricke, 1986; Holmberg, 1989; Kobayashi, 1989 for details of social organization and geographic variations). 


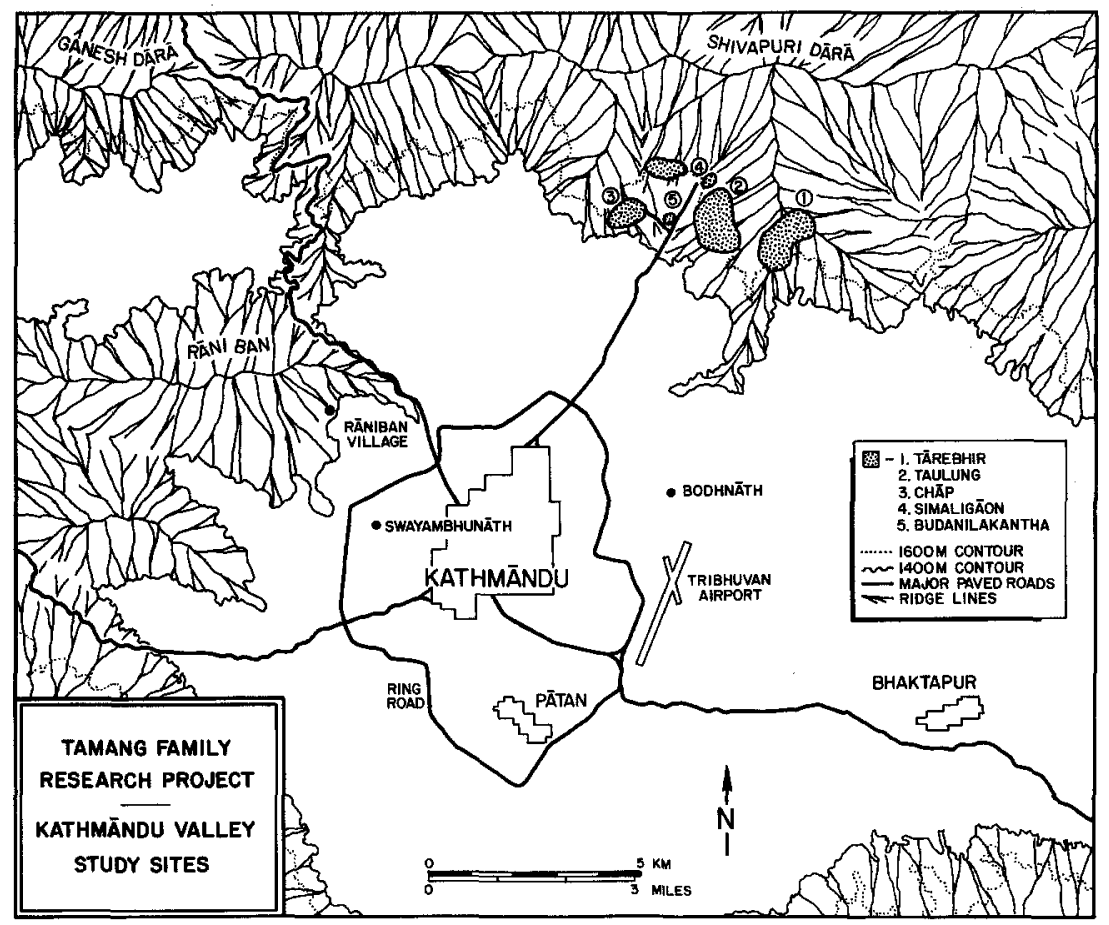

Fig. 1. Sangila, a settlement cluster of 307 Tamang households.

themselves on the densely forested slopes of Shivapuri, the second highest peak enclosing the Kathmandu Valley, and Sangila now stretches in a 3-mile arc from the valley floor at about $4500 \mathrm{ft}$ to a high point of about $6500 \mathrm{ft}$.

With the formation of the modern Nepali nation between 17691814 , these settlements were incorporated into a feudal system of sharecropping and corvée labor. Apart from these state and landlord requirements and their immediate implications for political kin networks (Fricke and Thornton, 1991), Sangila Tamang were free to pursue older cultural traditions and social organization (Höfer, 1979). Features of household and family organization included partible inheritance of immovable property among sons, a brideservice and indirect dowry system, bilateral cross-cousin marriage, and high rates of local endogamy (Fricke, 1986; Holmberg, 1989).

Sangila's agrarian system continued more or less undisturbed until the 1950-1951 reorganization of Nepal's government. This period marked 
the end of restrictions on schooling for the general public ${ }^{6}$ while opening the country to foreign development capital and the renewal of industries dormant since the nineteenth century (Rose and Fisher, 1970; pp. 129-134). At the same time, changing Sangila landlord-tenant relations freed people form corvée obligations and encouraged them to seek wage labor employment to buy their land.

The early impact of these changes was dampened by Sangila's marginal location at the edge of the Kathmandu Valley, but schools teaching up to grade 3 were built beginning in the early 1960's. Rapid expansion to keep up with the level of village students followed and four schools now exist in Sangila to provide classes through grade 10. More significant for the development of wage labor opportunities was the building of an allweather motorable road from Kathmandu. In the early 1960 's, a rutted dirt road allowed occasional access to Sangila but monsoon rains seasonally cut that link. By 1973 pavement extended to about half way between urban Kathmandu and the nearest households in Sangila. By 1975, regular bus and taxi service was established. Slightly before this in 1972, a prestigious boarding school intended primarily for wealthy outsiders was built within Sangila, giving rise to a growing bazaar near the terminus of the paved road.

Other developments nudging people into the wage labor economy included closing the higher slopes of Shivapuri to farming, grazing, and woodcutting in an effort to protect the major watershed for Kathmandu (Singh, 1986; Sthapit and Shrestha, 1986). This had the dual effect of ending household expansion into new arable land while truncating informal money-earning activities such as selling firewood in the city.

Most recently, carpet factories were opened in Sangila in the 1980's. The smallest factory in the Sangila area is the size of a small shop and employs six Tamang rug weavers, their looms set up along the walls. The largest carpet factory, on the other hand, employs over 100 weavers and encompasses a small compound in which employees eat, play cards, and nap during breaks. Within the compound are tin shanties for housing employees from beyond the village.

Economic and educational changes in Sangila are grafted onto a system where nearly every family's primary subsistence comes from agrarian

\footnotetext{
${ }^{6}$ Toward the end of the Rana prime ministership, under which Nepal existed in isolation for over 100 years (Rose and Fisher, 1970), educational reforms had begun but had yet to be widely implemented. Prior to these reforms, common people could learn to read and write with the aid of private tutors or from teachers supported at some temples by village and town philanthropists. Such a school was established at an important temple complex in Sangila in 1936. Three other schools in the settlements comprising Sangila were opened in 1961, 1972, and 1978.
} 
production. Yet, there has never been a time in living memory when people from these villages were not combining outside labor with family farm activities. Even the earliest British visitors to Kathmandu mention the Tamang as laborers for the elites of the capital (Buchanan, 1971; Hodgson, 1874; Wright, 1972). Nevertheless, the sudden introduction of schooling, new and extensive wage labor opportunities, and motorable roads means that the world of Sangila's young people has been fundamentally changed from that of their parents and grandparents.

\section{EXPECTED IMPACT OF HISTORICAL CHANGES ON FAMILY AND LIFE COURSE EXPERIENCES}

Work in Sangila includes a continuum from long established to novel forms of nonfamilial wage labor. Here we are most interested in wage labor activities which are not organized within or among families in the village environment. Family farm production for home consumption or sale and working on the farmsteads of other village families are consistent with historical patterns of the Tamang family mode of organization. Wage labor work organized outside of the family and village environment, on the other hand, represents a displacement of activities from high levels of familial control and is connected in theoretical models with far reaching changes in family relationships (Caldwell, 1982; Macfarlane, 1986).

In many respects, the rise of factory employment is the most interesting development for a theory of family and industrialization. For women, the carpet factories of Sangila offer the best possibility for wage labor employment outside of the domestic sphere much as the textile industry gave women prospects for wage work in New England and Europe (Hareven, 1982; Tilly and Scott, 1987). Unlike most of the other formal occupations engaged in by the people of Sangila, the carpet factories offer the opportunity for significant wage employment within the village area while being associated with the weaving tasks historically carried out by women (March, 1984).

We expect decisions to participate in these new opportunities to be shaped by characteristics at the individual, family, and community levels. Among important considerations is the continuity of new activities with culturally established roles and responsibilities, expectations based on gender and family status, and compatibility with crop production for household consumption. It is therefore useful to consider features of social organization that define individual interests within the domestic unit. Relevant features of family organization in Sangila include: 
1. The primary interests defining those of the domestic group are those belonging to the longest term residents and those with expectations of being connected to it the longest time in the future. These are usually the oldest couple within the unit; they are able to direct their children's activities until at least the time of marriage. The division of labor within the domestic unit tends to place women in positions of primary responsibility for activities performed in the village area.

2. Patrilineal organization of household fission insures that sons build new homes nearby after they leave, potentially contributing to their parents throughout their life. Older sons (if there are more than one) bring in a wife and initiate a process of household fission that often divides their focal loyalties from the natal family to the potential new domestic unit. There is inherent tension between an older son's wife and his parents.

3. Daughters, too, leave the household, but without strict division of domestic property. Ideally they will marry into a nearby clan neighborhood, but even when they move far from home and contribute minimally after marriage they can help to accumulate their own small inheritance of moveable property and be far less economically disruptive in leaving than sons.

4. In general, sons potentially contribute throughout their lives because they are expected to always live nearby. Daughters contribute mainly until they marry and leave with movable property and, possibly, small garden plots. Daughters-in-law are perceived as a potential wedge between a son and his natal home, as possessing divided interests, and thus regarded with some distrust.

These features of Sangila's family mode of organization imply that participation in the growing wage labor economy will be primarily structured by the dimensions of gender and life course position. We expect males and females to behave differently since their roles within the domestic economy fundamentally differ. ${ }^{7}$ At the same time, important life-course positions defined by the individual watersheds of marriage and the assumption of seniority within domestic groups alter a person's familial roles in ways that are expected to affect wage labor participation.

Gender. In the last section we stressed the association of women with tasks around the household in the predominantly agrarian system. Many current wage earning jobs, such as selling food, selling products from the family farm or nearby forests, craft production, and working on neighboring farmsteads for wages, are continuous with those of the past. They are

\footnotetext{
${ }^{7}$ Note that we are not generalizing from Sangila to all Tamang communities. Ethnographic materials demonstrate a good deal of variation in gender-related activities from setting to setting (Acharya and Bennett, 1981; Fricke and Thornton, 1991).
} 
all in some sense extensions of the domestic mode of production and we expect them to be represented in roughly equal measure by senior men and women since the order of authority in them is identical with family authority.

Other jobs are expected to be restricted largely to males, their common feature being not that they require more skill or special training available only to men, but that they take people away from the village. Such jobs have tended to be associated with men much as corvée labor requirements in Sangila were fulfilled by men rather than by both sexes. ${ }^{8}$

Life-Course Position. Relevant family positions for both genders were defined by the personal events of marriage and domestic group fission. Marriage marked the time when women left their natal homes and older sons began to prepare for eventual fission from paternal households; fission marked domestic seniority and full control over independent domestic economies. These events create three statuses within the domestic group: never-married dependent children, married juniors living with members of a senior generation, and married seniors in charge of domestic enterprises.

Given the historical lack of restrictions on male work, we expect life course effects on nonfamilial wage labor participation to be far less marked than among women. Differences across statuses are expected to result largely from the differential ability to command jobs. The youngest and the oldest men are least likely to be able to perform the demanding work mostly available to the Tamang. Moreover, many of these jobs became available long after older men had already assumed senior roles and many of these men had younger household members available to contribute their wages to the domestic economy. Finally, few reasons motivate seniors in control of the domestic economy to limit junior male participation in outside wage labor. Their work is viewed as an expansion of domestic activities (Fricke, 1986). When sons have married and begin thinking of forming independent units, undue restrictions on their activities may only hasten household fission. Furthermore, independent sons are likely to live close to their paternal homes and good relationships with them will insure economic cooperation of a high order after fission.

${ }^{8}$ Occupations away from the hearth are not necessarily associated with men among all Tamang. The community of Timling (Fricke, 1986) was not as directly subject to these corvée labor requirements, to the influences of high caste neighbors (Caplan, 1970, for a discussion of "sanskritization" in Nepal), nor to the truncation of local political networks dependent on kin. Significantly, Timling women move far afield in the search for wage labor employment, although usually in the company of related Timling men. 
Were it not for the existence of factories within the Sangila area, we might expect unmarried sons to be less involved in nonfamilial wage labor than other males if only because they would not qualify for many of the jobs available. Factory jobs requiring low skill levels and unappealing to senior males exist in the form of local carpet factories, however, and work in these is expected to raise the rate of participation in nonfamily employment for unmarried males. A corollary of this is that unmarried males will be far more represented in these factory jobs than those in later phases of the life course. Higher prestige and higher paying jobs, such as permanent government or office employment, became available to males later in the life course.

Life course effects for female participation in the nonfamily wage economy are expected to be more powerful than for males since marriage alters a woman's household position in far-reaching ways that include her relationships with other household members and her responsibilities as she begins bearing children. Junior unmarried daughters have historically contributed to the domestic economy as much as and even more than sons (Acharya and Bennett, 1981; Shrestha, n.d.). The only restriction on their involvement in nonfamilial wage jobs would thus seem to be the availability of culturally appropriate employment. Since daughters can be expected to turn most of their wages over to parents in the same way as sons there is no reason for parents to keep them from wage labor by virtue of their gender. On the other hand, restricting women to nearby job opportunities suggests that the primary nonfamilial wage work for women must be in local factories. Unmarried women should be as highly represented in nonfamily wage work as their unmarried brothers because such jobs are available in the area.

Marriage is expected to affect women's participation in wage labor, however, at first because a resident daughter-in-law's interests are directed toward the establishment of her own domestic unit with her husband. From the point of view of her husband's parents, who direct the domestic economy, her contribution to the common domestic fund is not assured. Where monetization is minimal, the distrust of a daughterin-law's loyalty built into the structure of household fission is kept in check since all labor contributes to a common domestic fund. Cash payment, however, allows women to set aside money for their future households. Daughters-in-law may thus be more useful on the farm where their effort is automatically directed to an indivisible domestic pool and where they free up unmarried members of the domestic group for wage work. These unmarried members are most likely to turn their earnings into that same common pool of resources. 
A second set of constraints keeping married women out of nonfamilial wage labor has to do with the mutual compatibility of activities. Mothers with suckling children will have their mobility reduced relative to those without and will be correspondingly less likely to work at occupations inconsistent with the demands of their children. ${ }^{9}$ We would expect, then, that daughters-in-law are less likely to work in the wage economy than unmarried daughters and that the propensity to work at these jobs is further diminished by having children. By the time women have moved into a position of seniority, we expect them to remain outside of nonfamilial employment because of continuing childcare responsibilities coupled with greater responsibility for managing the agricultural portion of the domestic economy.

Schooling represents an investment in the future contribution of a child to the domestic economy and does not yet enhance marital options as elsewhere in South Asia (Caldwell et al., 1988; Fricke et al., 1986). We expect sons to be represented more in schools than daughters since the latter are expected to remain within the family orbit for longer periods. Because most available work does not demand education, however, we suggest that the association between schooling and nonfamilial wage work turns on parents' perceptions of educational advantage rather than the real instrumental value of schooling as a prerequisite for wage work.

The primacy of family farm work leads us to an expectation about the relationship between the structure of domestic groups and individual wage labor participation. Since some wage earning possibilities are compatible with simultaneous involvement in the family farm while others are less so, we expect members of larger, more complexly structured domestic groups to be more likely to engage in outside occupations.

Finally, since the Sangila study area includes dispersed village clusters with differing access to transportation and differing qualities of land, we expect to find differences in participation in wage labor jobs by settlement. Access to urban areas has been taken as an inducement to social change in mountainous regions (Allan, 1986), the usual expectation being that reduced access will correlate with reduced participation in these activities. We suggest that other factors may override this simple relationship and Sangila households farthest from the roadhead will have greater proportional representation in nonfamily work than others

${ }^{9}$ It is far less an issue in village work since nursing children can accompany mothers in cooperative labor groups. Panter-Brick (1989) reports no difference in agricultural work rates between pregnant and lactating women and non-pregnant, non-lactating women in a western Tamang village. 
because of poorer land quality and restrictions on converting forest to farmland.

\section{DATA AND METHODS}

The Tamang Family Research Project. This analysis is based on 1987-1988 data gathered for the Tamang Family Research Project, a study exploring the impact of social and economic transformation on family relationships, life course transitions, and fertility. ${ }^{10}$ Survey data relate to life course transitions, their timing and content, and the household and kinship contexts within which they occur. Ethnographic information was gathered as part of a continuing study of Tamang social organization.

Survey data exist for all $1036^{11}$ Sangila Tamang defined as eligible respondents. Of these, 962 cases $(93 \%)$ come from interviews with the respondents themselves. A small number 74 (7\%), were not resident during fieldwork or were otherwise unable to be interviewed. Information for these people was collected by proxy interview with their spouse, parents, or sibs. Because the information solicited is largely behavioral, the quality of proxy data warrants inclusion in the analysis.

Variables. We categorize work activities by mode of organization (see Fig. 2) to distinguish (1) family farm work without pay and for home consumption and (2) all wage-earning work whether or not organized by the family. Within this second category we distinguish among (1) village work - wage earning activities organized within families, including truck farming or selling forest products, and farm work for wages, including wage labor exchanges between domestic groups within the Sangila area, and (2) all nonfamilial, non-agricultural work for wages. We are most concerned with the last category here. In addition, because factory employment has been shown to be an especially novel and theoretically interesting form of nonfamily employment we have constructed a variable for this.

\footnotetext{
${ }^{10}$ See Axinn (1989), Fricke et al. (1991), and Axinn et al. (1991) for methodological details. ${ }^{11}$ During data collection we defined eligibility (having reached age 12 ) in two ways. All individuals reported to be age 12 or older in the census we conducted were included in the eligible respondent pool. In addition, we took advantage of the indigenous animal year calendrical system (described in Fricke, 1986, p. 53) and included all individuals born in an animal year consistent with having reached age 12 whether or not they were reported to be a younger age on the census. We regard calculations from the animal year of birth to be more accurate representations of age than actual reported ages and here include only those respondents whose animal year of birth places them in the 12 or over category. Thus, our analysis is based on 1028 respondents and not the 1036 for whom we have information.
} 


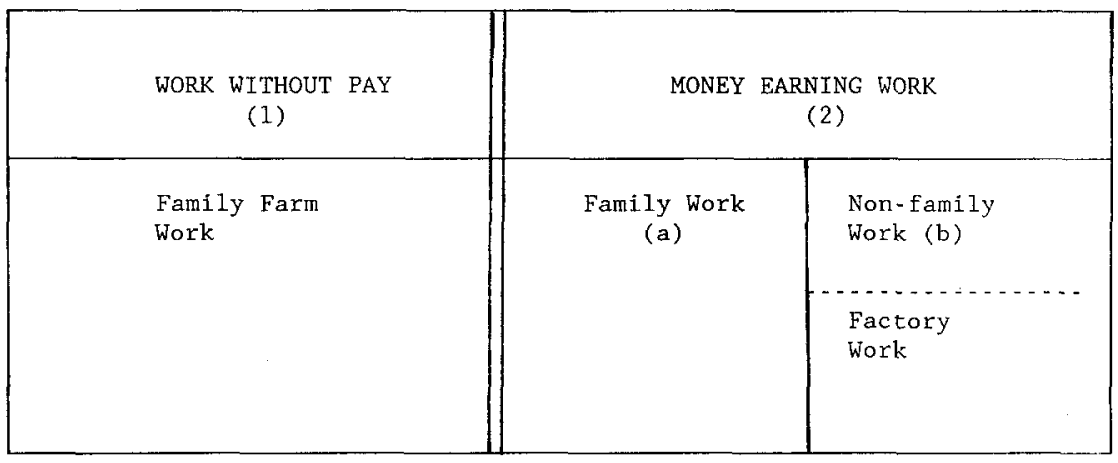

Fig. 2. Diagram of work categories discussed.

Our measure for education is restricted to whether or not respondents ever attended school, since preliminary analyses indicate that the important divide for both males and females is whether or not school was attended at all. ${ }^{12}$

Our categories for domestic group type, defined in terms of production rather than co-residence unit, include "simple," referring to nuclear or elementary units composed of a married couple alone, a couple with unmarried children, and single parents with unmarried children. "Stem" refers to a married couple or one surviving member of that couple sharing membership in the domestic group with one married child and his or her spouse. We have also included three generation extensions of this pattern into this category. "Extended-joint" domestic groups refer to those in which non-lineal relatives are members or in which parents and two sets of married children are resident. "Single" refers to men or women who have no other members of their group.

A person's relative position within the domestic group is determined by the dimensions of generation, gender, and whether or not they are members of their natal group. Using relationship to household head as the basis for defining categories, senior members are all those people in the same or ascending generation as the declared household head. Married junior members are here defined as all those people in the descending generations who have ever been married and who live in their natal home. Women in

\footnotetext{
${ }^{12}$ In earlier analyses we included literacy as an independent variable. Its eflects are virtually identical with those of any school attendance at all. Average attainment for those who have attended school is 4.6 years for males and 3.1 for females. Groupings by attainment result in extremely small numbers of women beyond grade 1. For most Sangila Tamang up to 1987, the value of school was primarily in attaining literacy.
} 
this category are either uxorilocally resident or not co-resident with their spouse. Unmarried juniors are members of a domestic group who had never been married at the time of survey. Our last category includes "daughtersin-law," 13 married members of the junior generation not resident in their natal home.

Four settlement clusters may be expected to differ in the behavior of their residents to the extent that location and ecological variations are important. They are: Taulung $(2),{ }^{14}$ the largest single settlement with households located along the entire range of altitudes; Simaligaon (4), a smaller cluster of households strung along a high hill away from the road; Budanilakantha-Chaap $(3,5)$, straddling the paved road into Sangila and including carpet factories and the bazaar; and Tarebhir (1), the cluster highest in altitude and the farthest walk from the road and factories.

Method of Analysis. Methods for the analysis of the quantitative data involve two procedures. The first is to use life table methods to examine historical trends in the entrance of men and women into village-centered work, wage work, and schooling. We do this for five tenyear birth cohorts.

Our second procedure involves the use of reports of work experience for the 12 months preceding fieldwork. We use this information together with current household information to more closely explore relationships between work participation and familial characteristics. The next step in analysis uses logistic regression to examine particular hypotheses relating women's participation in nonfamilial wage work to aspects of family organization and life course position (Morgan and Teachman, 1988).

\section{RESULTS}

\section{Trend Analyses}

Schooling, Occupations, and Gender. Table I presents the proportion of males and females at least 12 years old who have ever worked at specific

\footnotetext{
${ }^{13}$ We call these women daughters-in-law to avoid unnecessary confusion. Most of these women are daughters-in-law in ways consistent with English language use, but the cultural context casts a wider net. Included here are all junior female in-laws whether or not they are actually the wife of a household head's son.

${ }^{14}$ Numbers refer to the settlement numbers on Fig. 1.
} 
Table I. Proportion of Residents Age 12 and Over Ever Participating in Specified Work and School Activities, by Sex of Respondent ${ }^{a}$

\begin{tabular}{ccc}
\hline Activity & Male & Female \\
\hline 1. Family farm for own consumption & .914 & .968
\end{tabular}

2. Family farm production for sale
A. Family farm work
B. Selling wild products

.228

.273

.090

.044

3. Farmwork for wages

4. Servant

5. Proto-industrial work

A. Traditional selling Selling food

Other small-scale selling

B. Skilled crafts

6. Formal economy/industrial work

A. Unskilled labor

Portering/hauling loads

Construction, road work

B. Skilled or independent

Contractor, skilled building

Carpenter/mason

.000

\section{Driver}

C. Factory

Carpet

$.098 \quad .136$

Other

D. Government or office

$\begin{array}{lll}\text { Army } & .204 & .000 \\ \text { Botanical/forestry } & .022 & .000 \\ \text { Officework (peon or guard) } & .084 & .008 \\ \text { Other office work } & .042 & .008\end{array}$

7. Attended school 
production tasks or attended school at least once in their lives. ${ }^{15}$ We can see the extent to which subsistence agriculture has dominated individual work activities in Sangila. Over $90 \%$ of both men and women have worked on their family farms without pay and for family consumption (Activity 1). In spite of this, however, the large proportions of individuals who have been involved in money-earning demonstrates the extent to which the economy has been monetized. Nearly a third of these men and women have also been involved in farm production or forest gathering for sale (Activities $2 \mathrm{~A}, 2 \mathrm{~B}$ ). Over a third of the males have worked in formal wage work (Activities 6A-6D) although few of these jobs can be construed as "white collar" or "professional."

Finally, note the highly gender skewed nature of work outside of the village area. Tasks which may be performed in the village area (Activities $1-3,5)$ are more or less equally engaged in by men and women. The most organized parts of the formal economy, however, are distinguished by the extent to which females do not participate. Women are much less likely than men to have been involved in unskilled labor such as construction and hauling, in skilled or independent employment, or in government and office work. The exception to this pattern appears in the carpet factories where $13.6 \%$ of the female respondents and $9.8 \%$ of the male respondents have worked. This gender cleavage holds for proportions of men and women who have attended school in their lives. Nearly half of the male respondents have attended compared to only about a tenth of the females.

Rates of Entry into School and Jobs. Table II presents life table estimates for cumulative proportions who have attended school or worked at three categories of employment for each 5 years of age from 5 to 30 . These are broken down by birth cohort and sex to give an indication of historical trends in these activities by gender. Categories for income generating work include (1) family enterprises and work for wages on other farms, (2) all work for wages outside of family enterprises and agriculture, and (3) factory work by itself.

Schooling is obtained by increasing proportions with each new birth cohort. The first panel of Table II shows how schooling was restricted to a small percentage of males before the 1950-1951 change of government. For the males born before 1936, only $7.8 \%$ had attended school by age 15 . None of the women of this birth cohort attended school. All post-1936 cohorts are influenced by the sudden expansion of schooling opportunities,

\footnotetext{
${ }^{15}$ For work activities, the data refers to any event of at least a month or longer in each job category. Since many people have worked in multiple activities the sum over all economic involvement far exceeds $100 \%$.
} 


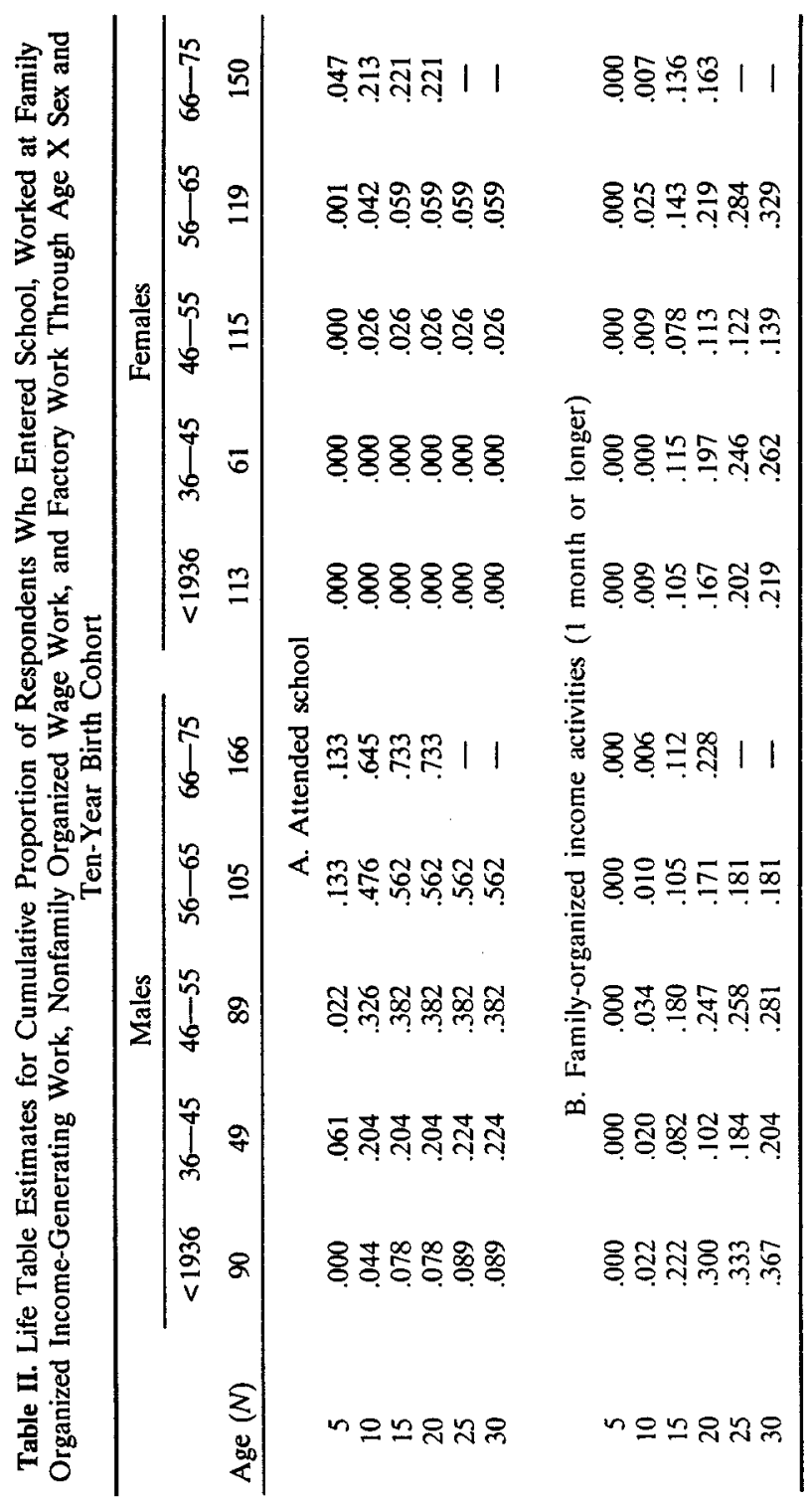




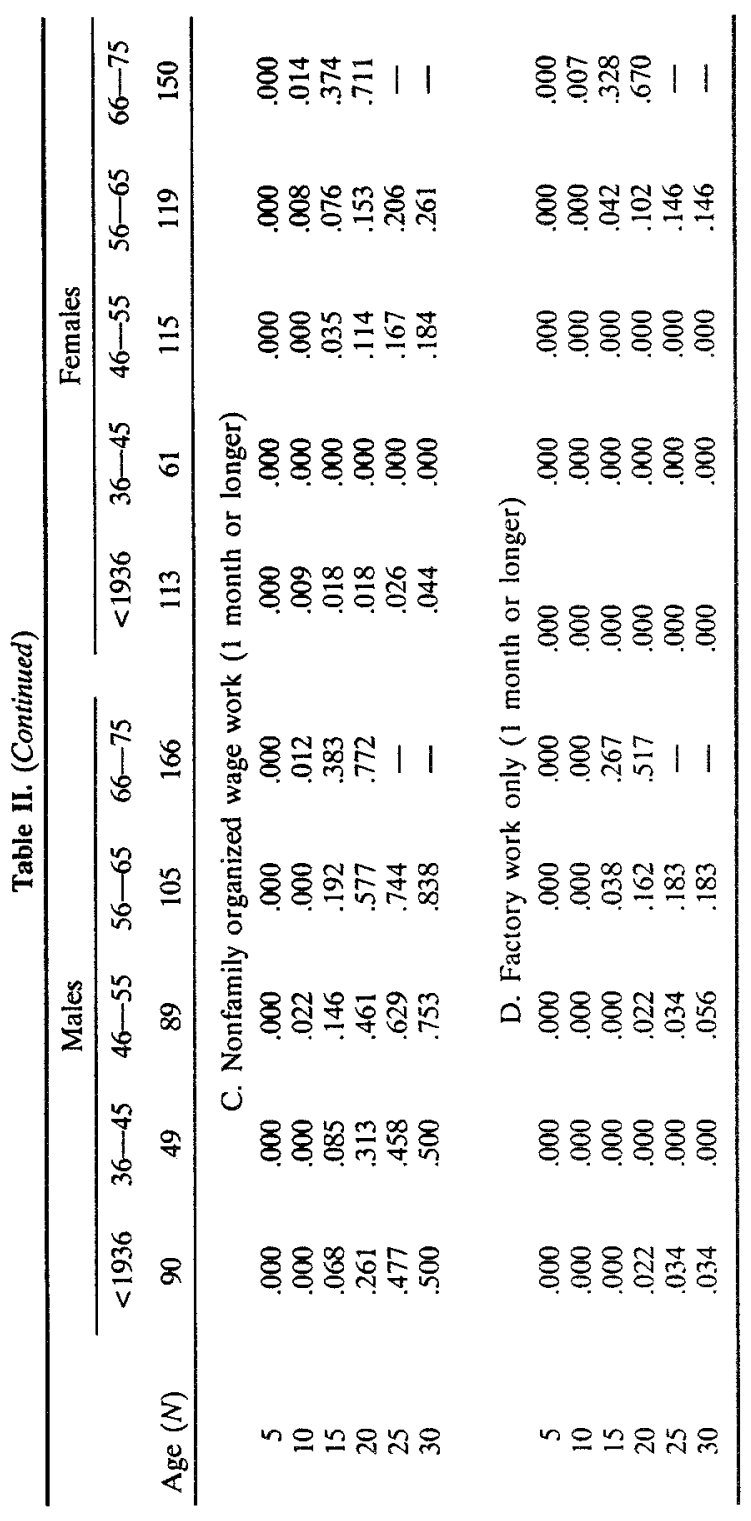


as shown by conspicuous increase across cohorts. Thus, $20 \%$ of the males born from 1936-1945 attended school by age 15 while more than two-thirds of those born between 1966-1975 are projected to do so. Female school attendance has also increased, but the onset of that increase occurred later and involves a smaller proportion than for males. For example, through the birth cohort of 1956-1965 the fraction of women who had attended school by age 10 was less than $3 \%$, but this increased to $21 \%$ for the youngest birth cohort. We can also see from the table that some males enter school for the first time after age 15 while this is hardly ever true for females. This may be related to the earlier marriages of females who are almost certainly not allowed schooling from the homes of their in-laws.

The next panel displays trends for participation in village work for pay - family enterprises generating monetary income and local agricultural work for pay. Here male participation across cohorts is somewhat uneven while the pattern for women also resists easy interpretation. It may be that these forms of income generation (including such activities as selling household distilled liquor and cutting and selling wood) represent family strategies for irregular short-term income needs but an adequate interpretation is beyond the scope of this paper.

Turning to the next panel, we can see the transformation of nonfamilial, non-agricultural labor opportunities in Sangila. The involvement of early cohorts of men is quite high, yet proportions regularly increase across cohorts. Taking the cumulative proportions of male participation by age 20 as a benchmark, we can see increases from $26 \%$ for the earliest birth cohort to $77 \%$ for the most recent. Nonfamilial wage work for the earliest cohorts is largely army, forestry, and peon work consistent with past corvée requirements for which small amounts of subsistence money was paid. The steady and dramatic increases in wage work from 19461955 to $1966-1975$, however, reflect trends in road building, construction, and factory work.

This last category, factory work, is shown in the final panel. With the 1956-1965 and 1966-1975 birth cohorts, we find females entering occupations at about the same rate as men. One of the most interesting findings demonstrated in these tables is the strong interaction of factory participation with the life course position of both men and women. Carpet factories have become an important employer in the Kathmandu Valley in the last decade, employing people just entering their teenage years at the time the factories were established. While these employment opportunities have obviously transformed the work experience of young people, their impact on older people is probably also powerful, if indirect, operating through changing household labor diversification and relationships with younger kin. 


\section{Contemporary Patterns}

How does participation in these new opportunities relate to individual characteristics and family and domestic group organization? What sorts of people are most likely to participate in incipient wage labor opportunities outside of the family and village? Because the rise of wage labor activities is recent, we believe that the experience of respondents in the 12 months prior to fieldwork is indicative of many underlying relationships throughout the post- 1950 period. Table III $^{16}$ displays the proportion involved in two salient categories of work by several individual, family, and community characteristics separately for male and female respondents aged 15 and over. We note again the strikingly gender differentiated participation in most forms of nonfamilial work. The total proportion of males working at nonfamily wage work reached .50 while for women it was only .10 .

Birth cohort measures both age and time of birth. For both men and women, younger age groups participate in wage labor at much higher levels than their elders. This is as we would expect since our earlier life table analyses showed such strong interaction between period and age. The relationship is most pronounced for women, however, as we would expect if young unmarried women are permitted greater leeway in their productive activities than married women.

Schooling is positively related to wage work rates for both women and men, but the relationship is statistically significant only for women. The low levels of actual attainment and the forms of employment Sangila Tamang are typically involved in suggest to us that this relationship is not driven by the nature of the labor market, but rather by familial perceptions of schooling's value. That is, most of the jobs these Tamang are likely to get do not require schooling to be performed. On the other hand, our informal conversations with Sangila residents suggest that they themselves perceive schooling to make a difference in obtaining nonfamilial employment. We suspect that parents who are inclined to direct their children to the nonfamily work arena are also likely to send their children to school. Moreover, it may even be that children who attend school are encouraged to seek such employment. Hence, the relationship between schooling and nonfamily work seems to derive from familial organization and perceptions rather than labor force requirements themselves.

\footnotetext{
${ }^{16}$ Tables III and IV represent the results of mulliple classification analysis (see Andrews $e t$ al., 1973 for details and interpretation of significance levels).
} 
Table III. Proportions of Women and Men Aged 15 or Older Engaged in any Nonfamilial Work and Factory Work Separately During 12 Months Before Interview by Individual, Family, and Settlement Characteristics

\begin{tabular}{|c|c|c|c|c|c|c|}
\hline \multirow[b]{2}{*}{ Variables } & \multicolumn{2}{|c|}{ Number of cases } & \multicolumn{2}{|c|}{$\begin{array}{l}\text { All nonfamily } \\
\text { work }\end{array}$} & \multicolumn{2}{|c|}{$\begin{array}{c}\text { Factory work } \\
\text { scparately }\end{array}$} \\
\hline & $\mathbf{M}$ & $\mathrm{F}$ & $\mathbf{M}$ & $\mathbf{F}$ & $\mathbf{M}$ & $\mathbf{F}$ \\
\hline Total $^{a}$ & 425 & 468 & .50 & .10 & .13 & .10 \\
\hline
\end{tabular}

Birth cohort $^{b}$

$<1936$

1936-1945

1946-1955

1956-1965

1966-1972

Significance of $F$

$\begin{array}{rrrrrr}90 & 114 & .22 & .02 & .03 & .00 \\ 49 & 61 & .39 & .03 & .00 & .00 \\ 89 & 84 & .60 & .04 & .01 & .00 \\ 104 & 118 & .61 & .14 & .07 & .11 \\ 93 & 91 & .61 & .41 & .32 & .38 \\ & & & c & c & c\end{array}$

Attended school

No

Yes

Significance of $F$

442

$.42 \quad .10$

$\begin{array}{ll}.08 & .08\end{array}$

$170 \quad 43$

$.62 \quad .54$

$.12 \quad .46$

Status within domestic group

Senior

Married Jr.

Unmarried $\mathbf{J r}$.

Female in-law

Significance of $F$

Type of domestic group

Simple
Stem
Extended
Single
$\quad$ Significance of $F$

Settlement

Taulung

Budanila-Chaap

Simaligaon

Tarebhir

Significance of $F$

$\begin{array}{rrrrrr}258 & 304 & .44 & .03 & .04 & .00 \\ 109 & 22 & .62 & .32 & .14 & .32 \\ 58 & 38 & .53 & .68 & .28 & .63 \\ & 104 & \bar{c} & .18 & -\bar{c} & .15\end{array}$

${ }^{a}$ Total number of cases and total proportions separately of men and women working in the various money-earning activities for at least 1 month of the past year.

${ }^{b}$ For this and subsequent panels, the proportions are based on the total number of individuals within each cell.

${ }^{c}$ Significant at the .01 level.

${ }^{d}$ Significant at the .05 level. 
A person's family status strongly affects rates of participation in wage employment. This is especially true for women and in ways consistent with our expectations. Note especially that daughters-in-law have extremely low probabilities of being involved in the nonfamily economy where they have greater potential control over the money they earn. ${ }^{17}$

Household type is not significantly related to participation in any activity. This is surprising given our expectations of family size and the ability to devote surplus labor to the wage labor economy. It is possible that extensive cooperative networks at more inclusive lineage levels, a widespread characteristic of Tamang social organization (Fricke, 1986; Toffin, 1986), moderate the effects of labor limitations within any single domestic group in isolation.

Settlement within Sangila is strongly related to wage work activities for both sexes. Tarebhir residents, despite being furthest from the road, have the highest likelihood of working in nonfamily employment. Given the usual expectations about access to transportation, this is at first surprising. It is more understandable when we consider that Tarebhir occupies the least desirable land within Sangila and is least likely to produce crops for sale. In addition, Tarebhir, up against the forest of Shivapuri, has been most affected by closure of the watershed to arable land expansion and wood cutting for sale. Thus, the opportunities for involvement in village centered enterprises are truncated by policies originating outside the community. Given the orientation of the domestic economy toward fulfilling the basic needs of the producing unit, it becomes necessary for these domestic groups to send members into the wage economy to make ends meet. ${ }^{18}$

These bivariate relationships demonstrate how powerfully age, schooling, status within domestic groups, and ecological factors can structure participation in new forms of production. Yet, the close relationship among these variables, for example, between age and schooling or age and status within families, makes it difficult to know what influences predominate. Because multicollinear effects of these variables make it difficult to proceed

\footnotetext{
${ }^{17}$ Ongoing analyses of actual income flows for this arca show that $58 \%$ of those few daughters-in-law who worked at nonfamilial wage labor reported keeping most of their earnings. Only $25 \%$ of those who received wages for farm work in the village area reported keeping most. For unmarried daughters only $10 \%$ of those working in nonfamilial wage labor reported keeping most of their earnings.

${ }^{18}$ For Tarebhir, this has resulted in a distinction between households defined by co-residence and domestic groups defined by co-production. Domestic groups in Tarebhir are more likely than any of the other settlements to include members resident in Kathmandu in satellite households near their work place and from which they contribute money to the pooled economy centered in the village. None of the other setlements has developed this option to the extent found in this distant location.
} 
Table IV. Proportions of Never-Married Women and Men Aged 15-21 Not Attending School in Past Year Engaging in Factory Work and Nonfamilial Work in the Last 12 Months by Family Characteristics

\begin{tabular}{|c|c|c|c|c|c|c|}
\hline \multirow[b]{2}{*}{ Variables } & \multicolumn{2}{|c|}{$\begin{array}{l}\text { Number } \\
\text { of cases }\end{array}$} & \multicolumn{2}{|c|}{$\begin{array}{l}\text { All nonfamily } \\
\text { work }\end{array}$} & \multicolumn{2}{|c|}{$\begin{array}{c}\text { Factory work } \\
\text { separately }\end{array}$} \\
\hline & M & $F$ & $M$ & $\mathrm{~F}$ & $M$ & $\mathrm{~F}$ \\
\hline Total $^{a}$ & 51 & 32 & .57 & .72 & .33 & .66 \\
\hline \multicolumn{7}{|l|}{ Household type ${ }^{b}$} \\
\hline Nuclear/other & 26 & 17 & .42 & .77 & .23 & .71 \\
\hline Stem-extended & 25 & 15 & .72 & .67 & .44 & .60 \\
\hline \multicolumn{7}{|l|}{ Schooling } \\
\hline None & 22 & 26 & .64 & .69 & .36 & .65 \\
\hline Some & 29 & 6 & .52 & .83 & .31 & .66 \\
\hline \multicolumn{7}{|l|}{ Settlement } \\
\hline Taulung-Simaligaon & 35 & 20 & .60 & .70 & .29 & .65 \\
\hline Budanila-Chaap & 9 & 7 & .33 & .86 & .22 & .86 \\
\hline Tarebhir & 7 & 5 & .71 & .60 & .71 & .40 \\
\hline
\end{tabular}

${ }^{a}$ Total number of cases and total proportions separately of men and women working in the various money-earning activities for at least 1 month of the past year.

${ }^{b}$ For this and subsequent panels, the proportions are based on the total number of individuals within each cell.

${ }^{c}$ Significant at the .01 level.

with straightforward regression analyses using the whole population, we examine two subsets of the population aged 15-31 (that is, born from 1956 to 1972) in Tables IV and V.

Recall from the life table analyses in Table II that this period reflects the greatest acceleration of wage labor participation for women in particular; these are also the age groups most likely to be currently involved in wage labor work. Our earlier discussion and the results in Table III have drawn attention to three important status groupings defined by life course transitions of marriage and establishing one's own household: senior generation with co-resident married children, married young people either living independently or with seniors, and unmarrieds. Since the first category is composed largely of men and women from the pre-1956 cohorts, the analysis in Table III establishes their reduced likelihood of wage work in the past year; questions about the structuring of work turn, therefore, to the other groups.

In Table IV, we consider the implications of household type on the likelihood of nonfamily organized wage work for never-married males and 
females who have not attended school in the past year. In order to control for age, we select a group between 15-21 years old. The only significant relationship within male and female categories is that between household type and all nonfamily work for males. The very small number of cases makes statistical significance difficult to achieve even when the magnitude of effect is large, however, and we discuss the proportions working in various categories regardless of their significance. Note first of all, that among never-married young people, girls are more likely to be working for wages than boys and that this is largely due to the differential in locally available factory work; while nearly all female wage work is in factories, this is true of only slightly more than half of the wage working males. Indeed, the different rates of factory work between young men and women is significant at the .01 level while the different levels of overall nonfamily work approaches significance. This supports our earlier argument concerning the association of carpet weaving with female activities and the differential acceptability of jobs that take males and females far from the community. It is also consistent with the argument that parents have a greater interest in taking immediate advantage of daughters' potential contribution to the domestic fund before her marriage and relocation. ${ }^{19}$

Looking at the proportions of never-married young people working at wage labor by household type, we find evidence of an interaction with gender. Daughters within nuclear households are more likely to work than those from stem or extended households; the converse relationship holds for sons. The relationship for sons is as we would expect where diversification of the domestic economy is allowed by complex family structure. The pattern for females is somewhat more puzzling and may relate to the different likelihood of each household type to have sons contributing to the domestic economy. That is, all stem and extended households will have junior males able to actively contribute to the domestic fund in wage work while the nuclear household category will be more mixed. In households without sons, daughters may be more likely to be used for monetary contributions to the domestic fund.

Schooling for these never-married young people has a slight negative relation to work at nonfamily organized wage labor for males; the numbers of never-married females who have had schooling is too small to reach any conclusions. Since we have excluded all of those respondents who reported attending school in the previous year, the explanation for the pattern cannot be the incompatibility of wage work and schooling.

\footnotetext{
${ }^{19}$ Although some forms of work, such as road construction, may involve different pay scales for males and females, earnings in carpet factories are based on a piece rate and divided between all those helping to weave a particular carpet. The rates for boys and girls are thus equivalent and differential pay does not explain the gender difference in employment.
} 
The last panel of Table IV shows the effects of settlement on the propensity to engage in wage work among never-married young people. Since the numbers are so small, it is risky to make much of these except to note that the correlation between distance from transportation and wage employment appears to hold for young never-married daughters, but not for sons.

In Table $\mathrm{V}$, we turn our attention to young ever-married women and men between the ages of 22-31. Logistic regression ${ }^{20}$ results are presented for the effects of individual, family, and community characteristics on the propensity to engage in all nonfamily wage work and factory work separately. Significance levels are indicated for the effects of variables in the zero-order case and controlling for the effects of other variables. In order to compare the relative effect of status within the family and household type we have run separate models with these variables since they are so closely linked that they cannot be entered in the same equation.

Here we shift our focus and compare young daughters-in-law with wives of household heads in the same age group in order to explore the impact of the transition from in-law to senior household member. The question here is whether the responsibilities of childcare or relative autonomy account for the difference between wage labor participation rates of senior women and daughters-in-law in Table III. Work by Panter-Brick (1989) in a western Tamang community shows that having children had no effect on work levels in the agricultural village economy where work rhythms could easily accommodate childcare. Because we observed women in Sangila carpet factories working at the looms with suckling babies and young children beside them, we find it fruitful to explore the relationship among household status, having children, and factory work in more detail. In the top panel of Table $\mathrm{V}$, we are able to test the relative importance of having children and position in the family in keeping married women from wage work.

We can see from the zero-order relationships that having children is strongly and significantly related to the propensity of married women to work for wages. Of women with children, only $2 \%$ engaged in factory work in the previous 12 months and only $4 \%$ were involved in any kind of nonfamily wage work. These levels compare to $42 \%$ and $50 \%$ for the small number of married women without children. Daughter-in-law status also has a significant relationship with all wage and factory work in the zeroorder case, paralleling the results in Table III. Since we have restricted our

\footnotetext{
${ }^{20}$ See Aldrich and Nelson (1984) for a discussion of this method. This table presents results in a more intuitively understandable MCA format for ease of discussion.
} 
Table V. Proportions of the Ever-Married Women and Men Aged 22-31 Not Attending School in the Past Year Engaging in Factory Work and Nonfamilial Work in the Last 12 Months by Family Characteristics

\begin{tabular}{|c|c|c|c|c|c|c|c|}
\hline \multirow[b]{2}{*}{ Variables } & \multicolumn{4}{|c|}{ All nonfamily work } & \multicolumn{3}{|c|}{ Factory work } \\
\hline & $N$ & $\begin{array}{c}0- \\
\text { Order }\end{array}$ & Adj. ${ }^{a}$ & $\mathrm{Adj}^{b}$ & $\begin{array}{c}0- \\
\text { Order }\end{array}$ & Adj. ${ }^{a}$ & $\mathrm{Adj}^{b}$ \\
\hline
\end{tabular}

\section{A: Women}

\section{Household type}

Nuclear/other

Stem-extended

$\begin{array}{lllllll}57 & .09 & .05 & - & .05 & .02 & - \\ 46 & .11 & .04 & - & .09 & .02 & -\end{array}$

Status in family

Senior

In-law

$\begin{array}{lllllll}58 & .05 & - & .04 & .02 & - & .01 \\ 45 & .16 & - & .05 & .13 & - & .03\end{array}$

Own children

$\begin{array}{llllllll}\text { None } & 12 & .50 & .41 & .37 & .42 & .26 & .19 \\ \text { Some } & 91 & .04 & .03 & .03 & .02 & .01 & .01 \\ & & c & c & c & c & c & c\end{array}$

Settlement

$\begin{array}{llllllll}\text { Taulung-Simaligaon } & 60 & .03 & .02 & .02 & .02 & .01 & .01 \\ \text { Budanila-Chaap } & 22 & .09 & .07 & .07 & .05 & .03 & .03 \\ \text { Tarebhir } & 21 & .29 & .18 & .18 & .24 & .12 & .10 \\ & & d & d & d & d & d & { }_{c}^{c}\end{array}$

B: Men

Household type

Nuclear/other

Stem-extended

\begin{tabular}{|c|c|c|c|c|c|}
\hline 46 & .63 & .65 & - & .13 & .12 \\
\hline 51 & .61 & .61 & - & .02 & .02 \\
\hline
\end{tabular}

Status in family

$\begin{array}{llllllll}\text { Senior } & 42 & .63 & - & .67 & .08 & - & .09 \\ \text { Junior } & 55 & .61 & - & .60 & .06 & - & .05\end{array}$

Schooling

$\begin{array}{llllllll}\text { None } & 42 & .55 & .57 & .57 & .07 & .04 & .07 \\ \text { Some } & 55 & .67 & .68 & .68 & .07 & .04 & .06\end{array}$

Settlement

$\begin{array}{lllllllll}\text { Taulung-Simaligaon } & 62 & .53 & .54 & .53 & .05 & .03 & .05\end{array}$

$\begin{array}{llllllll}\text { Budanila-Chaap } & 17 & .71 & .71 & .71 & .06 & .04 & .06\end{array}$

\begin{tabular}{llllllll} 
Tarebhir & 18 & .83 & .83 & .84 & .17 & .13 & .18 \\
& & $c$ & $d$ & $c$ & .17 & .13 & \\
\hline
\end{tabular}

${ }^{a}$ All variables except status in family entered.

${ }^{b}$ All variables except household type entered.

${ }^{c}$ Significant at .01 level.

${ }^{d}$ Significant at .05 level.

${ }^{e}$ Significant at .10 level. 
analysis here to women of roughly the same age, we can be confident that this difference is not a simple age effect.

When all variables are entered together in the adjusted column, the effects of status within the family washes out entirely while having children retains its significance in spite of a slight reduction in the magnitude of effect. Note, too that separate equations for household type shows it to be without effect while the impact of settlement shows that Tarebhir's women are more likely to be involved in wage work of all kinds in spite of their distance from the road.

The second panel of Table $V$ is intended to explore the effects of schooling on wage labor participation for men. In Table IV, we found a weak and counter-intuitive relationship for unmarried young people. Here we explore the relationship for young married men controlling for household structure, position within families, and settlement. Zero-order relationships indicate that education has no effect at all on factory work; when we consider all wage work together, we find that the direction of effect is as predicted although the relationship is not significant at the .10 level. Moreover, when variables are entered together in the adjusted column, settlement is the only variable with a significant relationship to participation in all wage work and Tarebhir shows the highest incidence of such participation.

\section{DISCUSSION AND CONCLUSIONS}

Nepali contexts of change are especially worthy of investigation because many of the general transformations, such as that from subsistence agricultural to wage labor production, which have occurred in the distant past in other settings may now be observed in process. To say that family and community contexts structure individual participation in novel educational and economic activities is to draw discussion to local systems of organization and relationship with outside opportunities. Here, we have focused on the specifically Tamang family mode of organization and intracommunity variation in proximity to transportation and access to high quality land.

Our expectations were that individual participation in wage labor opportunities would be structured by gender and generational relationships. The first of these expectations is supported throughout our analyses. A simple listing of proportions of men and women who have experienced various forms of work in Table I supports a view in which the more familial and village centered the organization of work, the greater the likelihood that it will equally involve men and women. Thus, quite similar proportions 
of men and women have worked at tasks that permit high levels of familial organization. Only for nonfamily organized wage work outside of the community, with the exception of carpet factories, do gender differentials become striking.

Subsequent tables also supported our expectations about the gender structure of work. The life table analyses in Table II showed that women's participation in village centered income activities began to approach that of men early on and is at roughly the same level in recent cohorts. They also suggest that men have been involved in outside wage labor for much longer than women and will likely continue to be involved at higher levels except for young people. For young men and women, our life table analyses suggest very similar levels of work at nonfamily organized labor in the group born since 1966. Further analysis indicates that this is largely because of the availability of factories in the community where it is acceptable for young unmarried women to work.

The interaction of age and gender is striking in the results in Table IV. Whereas for every other age group men work at wage labor at higher levels than women, unmarried young women are more likely to work at these activities than unmarried young men. This supports our reasoning that the monetary production value of daughters is best realized in the short term and is not replaced by women joining the household through marriage where sons are perceived as having a more long-term value.

Our expectations about wage labor participation and intergenerational relationships defined by marriage and residence are also largely supported by analyses. In Table III, we saw that young married women are far less likely to be currently involved in wage work than unmarried women but more likely to be working than senior women within households. The reasons for this appear to be the general age-structuring of employment opportunities combined with growing domestic responsibilities, including childcare, of married women in this setting.

Finally, our examination of settlement location within Sangila indicates that participation in new wage labor opportunities is not straightforwardly related to distance from transportation or work sites. Conditioning these relationships are local factors such as land availability and quality which may affect the motivation of individuals to pursue wage work as part of larger domestic strategies.

We believe these analyses highlight methodological, analytic, and substantive issues in the study of social change. Methodologically, we have demonstrated advantages that come from community studies that meld ethnographic and survey data collection. While such studies are not a substitute for large representative survey efforts (Axinn et al., 1991), 
they allow us to minutely examine new dimensions of variation in social change processes as, for example, in the U-shaped pattern of wage labor participation with respect to settlement proximity to work opportunities or our interpretation of the relationship between education and nonfamilial wage labor participation. The introduction of these more nuanced explanations in community studies of this type suggest possibilities for adding texture to the relationships we find in more expansive regional and national surveys.

Analytically, our analyses reaffirm the strategy of beginning with the nature of the social system itself as a way of understanding trajectories of social transition. Processes of monetization, rather than abstractly and linearly transforming societies in the same way, are themselves given shape by a particular setting's family mode of organization. Some have suggested, for example, that nuclear family organization is a spur to development of a formal wage labor economy. We have shown that, at least in Sangila, the content of relationships between family members provides a more powerful explanation of their work activities than household form by itself. Thus, across the whole population of Sangila, the status of people within families was more powerfully related to their participation in wage work than the structure of their domestic groups. When looking at people within the same status group, on the other hand, as we did for never-married respondents, we found that more complex households allowed for greater participation in nonfamily activities than nuclear types. Such a pattern is consistent with the perseverance of the family mode of organization in the face of changing economic activities and can only be understood with reference to preexisting family relationships.

Other findings reaffirm general patterns found in other settings. In European transitions, for example, married women were overwhelmingly removed from monetary contributions to the household economy (Davis, 1984). ${ }^{21}$ The same pattern holds in Sangila, where marriage removes women from wage work, at least during that life course phase when they are resident daughters-in-law.

Variables incorporating familial relationships, especially those revolving around gender and life course transitions, were consistently among the most significant in our models predicting nonfamilial work. Moreover, the interpretation of the effects of superficially nonfamilial variables, such as education or birth cohort, was shown to make sense when they were contextualized in terms of familial age, intergenerational relationships, and

\footnotetext{
${ }^{21}$ We refer to the dominant trend here. In particular cases, especially where coltage industry was dominant, women remained important contributors to domestic income flows in spite of their domestic responsibilities (Tilly and Scolt, 1987). This of course changed with the decreasing importance of these industries.
} 
perceptions motivating family strategies. At the early stages of monetization, the evidence from Sangila suggests that economic transformation is powerfully shaped by contextual factors within the family mode of organization itself.

\section{ACKNOWLEDGMENTS}

An earlier version of this paper was presented at the 1989 Population Association of America Meetings, Baltimore. Thanks to Judith Baughn, Tschering Lama, Meena Tamang, and Linda Young-Demarco for help in data collection, analysis, and manuscript preparation. We have also benefitted from the comments of Bill Axinn, Susan Greenhalgh, Charlie Hirschman, David Holmberg, Nancy Levine, Karen Mason, Ron Rindfuss, Dave Zurick, and two anonymous reviewers. Support for data collection and analysis was provided by the National Institute of Child Health and Human Development (Grant HD22543) and the National Science Foundation (Grant SES-8607288). We acknowledge permission from His Majesty's Government of Nepal to conduct field research.

\section{REFERENCES}

Acharya, M., and Bennett, L. (1981). The Rural Women of Nepal: An Aggregate Analysis and Summary of Eight Village Studies. Tribhuvan University Press, Kathmandu.

Aldrich, J. H., and Nelson, F. D. (1984). Linear Probability, Logit, and Probit Models. Quantitative Applications in the Social Sciences, No. 45. Sage Publications, Newbury Park, CA.

Allan, N. (1986). Accessibility and altitudinal zonation models of mountains. Mountain Research and Development 6(3): 185-194.

Andrews, F. M., Morgan, J. N., Sondquist, J. A., and Klcm, L. (1973). Multiple Classification Analysis. Institute for Social Research, Universily of Michigan, Ann Arbor.

Axinn, W. G. (1989). Interviewers and data quality in a less developed setting. Journal of Official Statistics 5(3): 265-280.

Axinn, W. G., Fricke, T. E., and Thornton, A. (1991). The microdemographic community-study approach: Improving survey data by integrating the ethnographic method. Sociological Methods and Research (forthcoming).

Bishop, N. H. (1989). From zomo to yak: Change in a Sherpa village. Human Ecology 17(2): 177-204.

Bista, D. B. (1967). People of Nepal. Ratna Pustak Bhandar, Kathmandu.

Buchanan, F. H. (1971). An Account of the Kingdom of Nepal and of the Territories Annexed to this Dominion by the House of Gorkha (originally published in 1819). Manjusri Publishing House, New Delhi.

Caldwell, J. C. (1982). Theory of Fertility Decline. Academic Press, New York.

Caldwell, J. C. (1985). Strengths and limitations of the survey approach for measuring and understanding fertility change: Alternative possibilities. In Cleland, J., and Hobcraft, J. (eds.), Reproductive Change in Developing Countries: Insights from the World Fertility Survey. Oxford University Press, London, pp. 45-63. 
Caldwell, J. C., Reddy, P. H., and Caldwell, P. (1988). The Causes of Demographic Change: Experimental Research in South India. University of Wisconsin Press, Madison.

Caplan, L. (1970). Land and Social Change in East Nepal: A Study of Hindu-Tribal Relations. University of California Press, Berkeley.

Dahal, D. R. (1983). Poverty or plenty: Innovative responses to population pressure in an eastern Nepalese hill community. Ph.D. dissertation in Anthropology, University of Hawaii, Manoa.

Davis, K. (1984). Wives and work: The sex role revolution and its consequences. Population and Development Review 10(3): 397-417.

Fricke, T. E. (1986). Himalayan Households: Tamang Demography and Domestic Processes. Iowa State University Press, Ames, Iowa.

Fricke, T. E., Dahal, D. R., Thornton, A., Axinn, W. G., and Rimal, K. P. (1991). Tamang Family Research Project Report. Center for Nepal and Asian Studies, Tribhuvan University, Kathmandu.

Fricke, T. E., Syed, S. H., and Smith (Xenos), P. C. (1986). Rural Punjabi social organization and marriage timing strategies in Pakistan. Demography 23(4): 489-508.

Fricke, T. E., and Thornton, A. (1991). Rethinking marital decision-making: Family mode of organization, social change, and marriage process in two Nepali communities. Paper presented at the Annual Meeting of the Population Association of America, Washington, D.C.

Hareven, T. (1982). Family Time and Industrial Time. Cambridge Universily Press, Cambridge.

Hitchcock, J. T. (1961). A Nepalese hill village and Indian employment. Asian Sulvey 1(9): 15-20.

Hitchcock, J. T. (1980). A Mountain Village in Nepal. Holt, Rinehart and Winston, New York.

Hodgson, B. (1874). Essays on the Languages, Literature, and Religion of Nepal and Tibet Together with Further Papers on the Geography, Ethnology, and Commerce of Those Countries. Trübner and Company, London.

Höfer, A. (1969). Preliminary report on ficld research in a western Tamang group, Nepal. Bulletin of the International Committee for Urgent Anthropological and Ethnological Research 11: 17-31.

Höfer, A. (1979). The Caste Hierarchy and the State in Nepal: A Study of the Muluki Ain of 1854. Universitätsverlag Wagner, Innsbruck.

Holmberg, D. H. (1989). Order in Paradox: Social Forms, Ritual Polarities, and Mythic Imagination among Nepal's Tamang. Cornell University Press, Ithaca.

Kertzer, D. I. (1984). Anthropology and family history. Journal of Family History 9(3): 201-216.

Kertzer, D. K., and Hogan, D. P. (1989). Family, Political Economy, and Demographic Change: The Transformation of Life in Casalecchio. Italy, 1861-1921. Universily of Wisconsin, Madison.

Kobayashi, S. (1989). Geographic and ethnic setting of arcas surveyed. In Ogata, M. (ed.), Comparative Epidemiological Studies on the Genesis of Hypertension in Nepal. Institute of Health Science, Kyushu University, Kyushu.

Levine, N. E. (1988). The Dynamics of Polyandry: Kinship, Domesticity, and Population on the Tibetan Border. University of Chicago Press, Chicago.

Macfarlane, A. (1976). Resources and Population: A Study of the Gurungs of Nepal. Cambridge University Press, Cambridge.

Macfarlane, A. (1986). Marriage and Love in England, 1300-1840. Basil Blackwell, Oxford.

March, K. (1984). Weaving, writing, and gender. Man (N.S.) 18(4): 729-744.

Medick, H. (1976) The protoindustrial family economy. Social History 3: 291-315.

Messerschmidt, D. A. (1976). Ecological change and adaptation among the Gurungs of the Nepal Himalaya. Human Ecology 4(2): 167-185.

Metz, J. J. (1989). A framework for classifying subsistence production types of Nepal. Human Ecology 17(2): 147-176.

Morgan, S. P., and Teachman, J. D. (1988). Logistic regression: Descriptions, examples, comparisons. Journal of Marriage and the Family 50: 926-936.

Nag, M., White, B., and Peel, R. C. (1978). An anthropological approach to the study of the economic value of children in Java and Nepal. Current Anthropology 19(2): 292-306. 
Netting, R. McC., Wilk, R. R., and Arnould, E. (eds.) (1984). Households: Comparative and Historical Studies of the Domestic Group. University of California Press, Berkeley.

Panter-Brick, C. (1989). Motherhood and subsistence work in rural Nepal. Human Ecology 17(2): 205-228.

Regmi, M. C. (1971). A Study in Nepali Economic History, 1768-1846. Manjusti Publishing House, New Delhi.

Regmi, M. C. (1978). Thatched Huts and Stucco Palaces: Peasants and Landlords in 19th Century Nepal. Vikas, New Delhi.

Rose, L. E., and Fisher, M. W. (1970). The Politics of Nepal: Persistence and Change in an Asian Monarchy. Cornell University Press, Ithaca.

Shrestha, I. (n.d.). Unpublished fieldnotes, Status of Women in Nepal Project, Katarche Village, Tamang.

Singh, P. B. (1986). Socio-Economic Survey of the Shivapuri Watershed. HMG, Ministry of Forests and Soil Conservation, Shivapuri Watershed Management and Fuelwood Plantation Project, Kathmandu.

Sthapit, K. M., and Shrestha, B. D. (1986). Watershed Development Plan of the Shivapuri Project Area. HMG, Ministry of Forests and Soil Conservation, Shivapuri Watershed Management and Fuelwood Plantation Project, Kathmandu.

Thornton, A., and Fricke, T. E. (1987). Social change and the family: Comparative perspectives from the West, China, and South Asia. Sociological Forum 2(4): 746-779.

Tilly, L. A., and Scott, J. W. (1987). Women, Work, and Family (2nd Ed.). Methuen, New York.

Toffin, G. (1986). Mutual assistance in agricultural work among western Tamang of Nepal: Traditional and new patterns. In K. Seeland (ed.), Recent Research on Nepal. Weltforum Verlag, Munich, pp. 83-96.

Wilk, R. R. (1990). Household ecology: Decision-making and resource flows. In Moran, E. F. (ed.), The Eco-System Approach in Anthropology: From Concept to Practice. University of Michigan Press, Ann Arbor, pp. 323-356.

Wilk, R. R., and Netting, R. McC. (1984). Households: Changing forms and functions. In Netting, R. McC., Wilk, R. R., and Arnould, E. (eds.), Households: Comparative and Historical Studies of the Domestic Group. University of California Press, Berkeley, pp. $1-28$.

Wright, D. (1972). History of Nepal (originally published in 1877). Nepal Anliquated Book Publishers, Kathmandu.

Yanagisako, S. J. (1979). Family and household: The analysis of domestic groups. Annual Review of Anthropology 8: 161-205.

Zurick, D. N. (1989). Historical links between settlement, ecology, and politics in the mountains of West Nepal. Human Ecology 17(2): 229-255. 